\title{
A KNOWLEDGE, ATTITUDE, AND PRACTICE ON DIABETIC FUNDUS EXAMINATION AMONG GENERAL PRACTITIONERS IN PUSKESMAS OF BANDUNG CITY
}

\author{
Nina Ratnaningsih ${ }^{1}$, Degiana Syabdini ${ }^{1}$, Medissa $^{1}$, Iwan Sovani², Syumarti ${ }^{1}$, \\ Mayang Rini ${ }^{1}$, Aldiana Halim ${ }^{1}$ \\ ${ }^{1}$ Community Ophthalmology Department of Cicendo Eye Hospital/ Medical Faculty of Padjadjaran University \\ ${ }^{2}$ Vitreoretinal Department of Cicendo Eye Hospital/Medical Faculty of Padjadjaran University
}

\begin{abstract}
Introduction: The prevalence of Diabetic Retinopathy (DR) and Vision Threatening Diabetic Retinopathy (VTDR) in Greater Bandung in 2017 was $24.7 \%$ and 9\%, respectively. almost 30\% of DR cases have become VTDR, although it could have been prevented. In the primary level of prevention, fundus examination is necessary to avoid VTDR. Some potential barriers, such as Knowledge, Attitude, Practice, and related factors, should be overcome. This research's objective was to assess Knowledge, Attitude, Practice (KAP), and associated factors on diabetic fundus examination among GPs in Puskesmas of Bandung City.
\end{abstract}

Methods: This research, based on a cross-sectional population study, was conducted from April to June 2020. it involved 115 GPs at 62 Puskesmas of Bandung City who fulfilled the eligibility criteria with purposive sampling. It used a self-administered KAP questionnaire on diabetic fundus examination. The data were presented in descriptive and analytical explanations using Chi-square with a p-value of 0.05 as a statistically significant result.

Result: The mean of Knowledge and Attitude on fundus examination was $70.67(95 \% \mathrm{Cl} \pm 3.26), 72.87$ (95\% $\mathrm{Cl} \pm 2.61$ ). These results were within the good criteria range. However, for Practice, the result was unsatisfactory for $95.65 \%$ participants. Poor Practice was significantly associated with direct ophthalmoscope ( $p=0.00038$ ) that couldn't be accessed by 98 of the participants (85\%). Other GPs with ophthalmoscope access still could not conduct a fundus examination because of the unavailability of mydriatics to dilate the pupil.

Conclusion: Knowledge and Attitude on fundus examination among GPs were good but low for Practice. It was correlated with direct ophthalmoscope and mydriasis availability. This needs an advocacy approach to overcome.

Keywords: Knowledge, Attitude, Practice, general practitioners, diabetic retinopathy Cite This Article: RATNANINGSIH, Nina. KNOWLEDGE, ATTITUDE, AND PRACTICE ON DIABETIC FUNDUS EXAMINATION AMONG GENERAL PRACTITIONERS IN PUSKESMAS OF BANDUNG CITY. International Journal of Retina, [S.I.], v. 4, n. 1, p. 9, feb. 2021. ISSN 2614-8536. Available at: <https://www.ijretina.com/index.php/ijretina/article/view/138>. Date accessed: 22 feb. 2021 . doi: https://doi.org/10.35479/ijretina.2021.vol004.iss001.138.

${ }^{*}$ Correspondence to:

Nina Ratnaningsih,MD

Universitas Padjajaran

Bandung, Indonesia

nratnanina@gmail.com

\section{INTRODUCTION}

The prevalence of Diabetic Retinopathy (DR) and Vision

Threatening Diabetic

Retinopathy (VTDR) in the

Greater Bandung area in 2017 was $24.7 \%$ and $9 \%$, respectively. Almost $30 \%$ of DR falls into VTDR category. Early detection and appropriate treatment for DR can reduce $60 \%$ of the risk of blindness. ${ }^{1,2}$

Indonesian government has developed a program for chronic diseases (PROLANIS) to facilitate social health insurance. Participants suffering from hypertension and type 2 diabetes in Primary Health Care $(\mathrm{PHC})$ will reduce the risk of 
complications and achieve a better quality of life. For reducing diabetic complications, the activity starts by identifying a person with type 2 diabetes among the community of the PHC working area, followed by risk factor monitoring such as glycaemic control, arterial hypertension, and nutrition status. Annually fundus examination should include monitoring risk factors by GPs due to the $4 \mathrm{~A}$ level of skill competencies for GPs in Indonesia. Direct ophthalmoscope should be available in Puskesmas, according to the Indonesia Ministry of Health rule (PMK) number 29/2016. If there are any fundus examination findings, due to the 2A level of skill competencies, GPs will refer the patients to get advanced examination by ophthalmologists. ${ }^{3,4,5}$

Data about Knowledge, Attitude, and Practice among GPs are essential information to reveal the obstacles and potential barriers for the DR early detection program in PHC. A Good Knowledge, Attitude, and Practice in fundus examination will enhance the benefit of reducing the blindness due to DR. Unfortunately, there were no researches on the Knowledge, Attitude, and Practice on fundus examination among GPs in Bandung City in Indonesia. Consequently, this research was conducted to assess the Knowledge, Attitude, Practice, and barriers on fundus examination among the GPs in Puskesmas of Bandung City.

\section{METHODS}

This cross-sectional study was conducted between April and June 2020 once approved by the ethical committee of Padjadjaran University. Inclusion criteria were all the GPs in all Puskesmas of Bandung City. GPs who were not in the contact list, could not be contacted with three calling attempts, or refused to participate, were excluded.

Due to the peak of COVID-19 pandemic during research, only a limited number of GPs were willing to participate in this research. Participants were chosen by purposive sampling. The protocol for filling questionnaire was described over the phone, and participants were asked to fill the selfadministered KAP questionnaire, which was sent by email. Questions were the part of the KAP questionnaire of DR screening in Bandung City. Questions were to test the Knowledge (11 items), Attitude (3 items), and Practice ( 1 item) of the GPs on matters associated with fundus examination. Participant Knowledge and Practice were scored with 1 for right answers, 0 for wrong answers. Participant attitudes were scored by the Likert scale. Scores were graded as good or poor Knowledge, positive or negative Attitude, and good or poor Practice. Good/positive Knowledge/Attitude criteria were given for scores $50 \%$ and above, Otherwise, poor/negative criteria were for score below 50\%. Good or poor practice criteria were for applying or not applying fundus examination statements. Respondent demographic data, responses, and corresponding scores were entered into Microsoft excel software and subsequently analyzed. Results were presented in tables and charts. Chi-square tests were performed between categorical variables to determine their level of statistical significance. A p-value of 0.05 was accepted as significant.

\section{RESULTS}

\section{Demographic Distribution}

There were 115 GPs from 62 Puskesmas in Bandung City who participated in this study. Actually, there were 78 Puskesmas divided into eight sub-areas of city development, and 62 of them were participants' working areas.

Table 1 shows that, the participants' median age was 31 years of age, ranging from 25 to 58 years old. After graduation, the median of experience was seven years, with $75.65 \%$ of participants having 1 10 years of experience. Ninety one percent of the participants were females, and $19.13 \%$ were working at Puskesmas in Cibeunying. Out of 61 Puskemas in this study, 17 participants from 15 Puskesmas (58.82\% in the west area and $41,18 \%$ in the east area) of Bandung city could access direct ophthalmoscope in their clinics. 
Table 1. Demographic Distribution

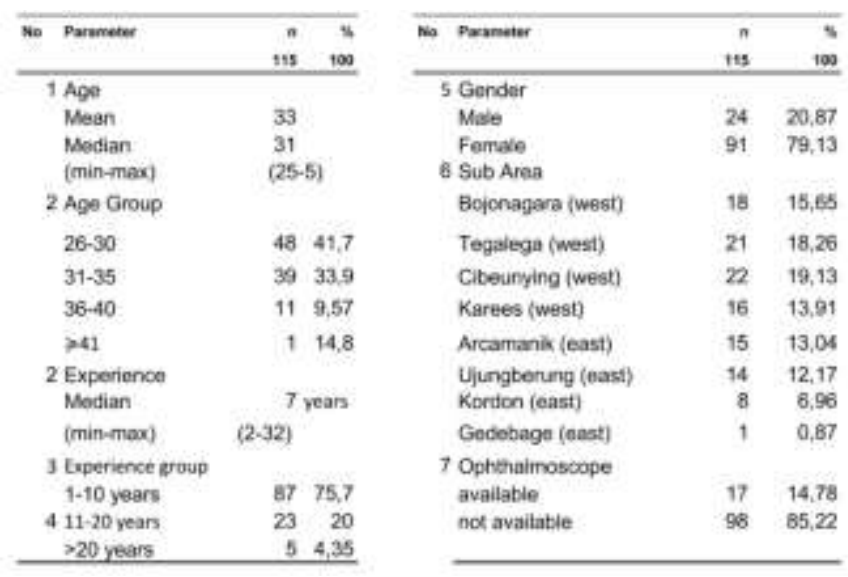

\section{KNOWLEDGE}

The mean of knowledge scores in this study was 70.67 (95\% Cl \pm 3.26 ). Diagram 1 shows that $84.3 \%$ of participants had a good Knowledge on fundus examination of diabetic patients. Diagram 2 shows participants' responses to 7 Knowledge questions about fundus signs and 4 Knowledge questions for fundus examination timing questions. The most incorrect answer related to fundus sign was macular changes, with only $9.57 \%$ correct answer $(n=11)$. Conversely, most of the participants $(\mathrm{n}=107,93.04 \%)$ knew about microaneurysms.

The most incorrect answer related to fundus examination timing was on pregnant diabetic patients, with only $20.87 \%$ correct answer $(n=24)$. The correct answer was the examination timing for No DR diabetic patients, with $80.87 \%$ correct answer $(n=93)$.

The mean of Attitude score was 72.87 (95\% Cl \pm 2.61). Diagram 1 shows that $93.04 \%$ of participants have a good attitude level. Diagram 3 shows participant responses to 3 attitude questions. Almost $70 \%$ of participants did not agree if the fundus examination was done only by ophthalmologists.

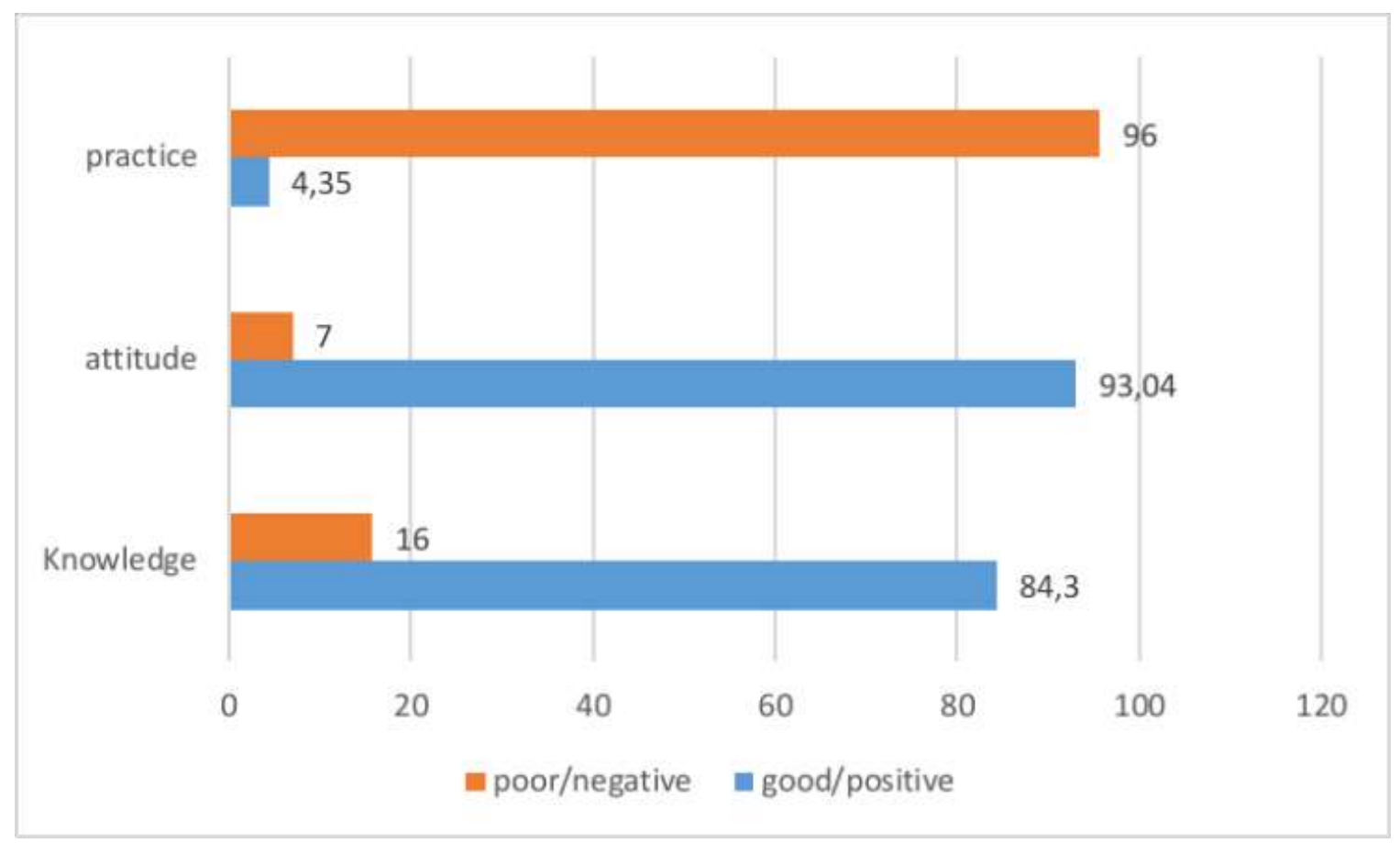

Diagram 1. Knowledge, Attitude, and Practice Distribution 
$73.91 \%$ agreed if GPs can detect DR with a direct ophthalmoscope. $40,87 \%$ of participants felt sufficient with fundus examination training at medical school. Diagram 4 shows the responses to
Practice questions, which were only 8 participants conducted fundus examination of diabetic patients (4.35\%)

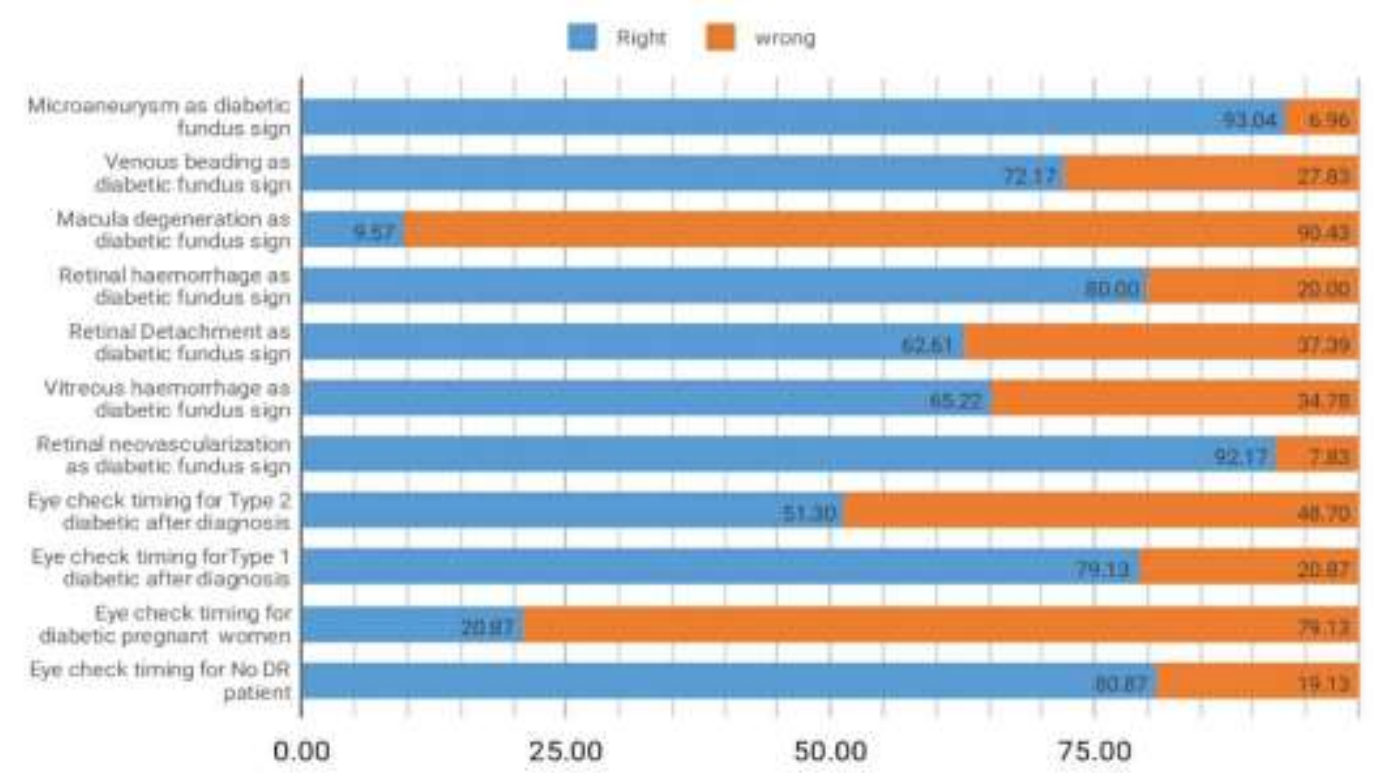

Diagram 2. Participant responses for Knowledge Questions about Fundus Examination Attitude and Practice

Fundus examination training in medical school was sufficient for GPs.

GPs should be able to detect fundus changes on diabetic patients.

fundus examination should be done by ophthalmologist only.

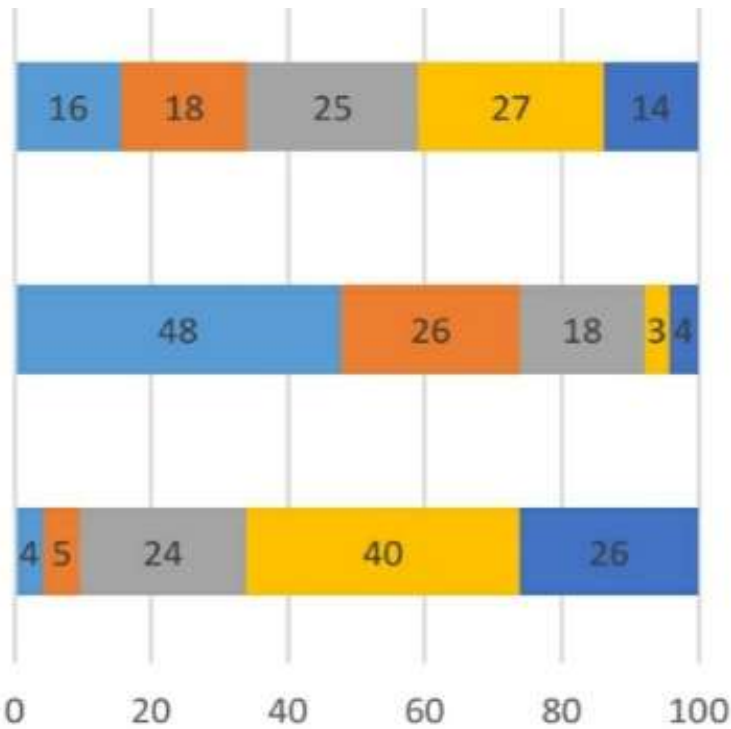

mstrongly agree $\mathbf{m}$ agree $\mathbf{m}$ not sure $\mathbf{m}$ not agree $\mathbf{m}$ strongly not agree

Diagram 3. Participant responses for Attitude Questions about Fundus Examination 
Diagram 4 shows that only $4.35 \%$ have a good practice level on fundus examination of diabetic patients.

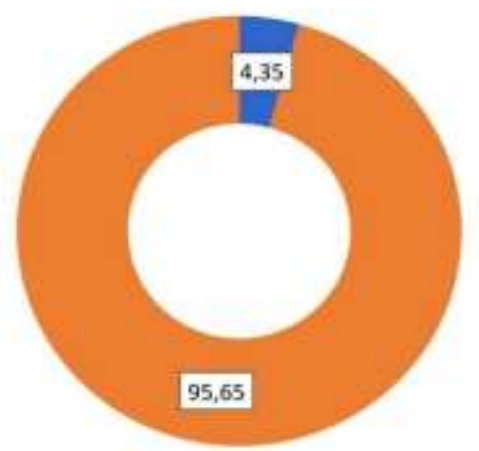

a spplyine a not applyine

Diagram 4. Participant responses for Practice Question about Applying Fundus Examination on Diabetic Patients

The implications of demographic factors on KAP are showed in Table 2. It shows that there was no statistically significant demographic difference related to the level of Knowledge and Attitude among participants. Still, there was a statistically considerable implication of the ophthalmoscope availability factor related to fundus examination practice $(p=0.0003)$. An interesting facts is a similar demographic trend for poor Knowledge and Attitude. They were dominated by age above 35 years old, working experience more than 20 years, and male. Also, participants with ophthalmoscope supporting in their clinic were included $76.5 \%$ (13 out of 17) as poor Practice on fundus examination among GPs.

\section{Barriers for Fundus Examination Among GPs}

The participant perceived barriers for fundus examination are described in the diagram 5 . There were different barriers between the group with available ophthalmoscope and the group without ophthalmoscope. There were six barriers mentioned as, time-consuming, no tools, lack of skill, no mydriatics, patient refused, and others.

Table 2. Demographic Factors Related to Knowledge, Attitude, and Practice on Fundus Examination

\begin{tabular}{|c|c|c|c|c|c|c|c|c|c|c|c|c|c|c|c|c|c|c|c|c|c|}
\hline \multirow[b]{2}{*}{ Demographic Distribution } & \multicolumn{4}{|c|}{ Knowledge } & \multirow{2}{*}{\multicolumn{2}{|c|}{$\begin{array}{l}\text { Total } \\
n \%\end{array}$}} & \multirow{3}{*}{ p } & \multicolumn{4}{|c|}{ Attitude } & \multicolumn{9}{|c|}{ Practice } & \multirow[b]{2}{*}{ p } \\
\hline & \multicolumn{2}{|c|}{$\begin{array}{c}\text { Good } \\
\mathrm{n} \%\end{array}$} & \multicolumn{2}{|c|}{$\begin{array}{l}\text { Poor } \\
n \%\end{array}$} & & & & \multicolumn{2}{|c|}{$\begin{array}{c}\text { Positive } \\
n \%\end{array}$} & \multicolumn{2}{|c|}{$\begin{array}{c}\text { Negative } \\
n \%\end{array}$} & \multicolumn{2}{|c|}{$\begin{array}{l}\text { Total } \\
n \% \\
\end{array}$} & \multirow[t]{2}{*}{ p } & \multicolumn{2}{|c|}{$\begin{array}{c}\text { Good } \\
n \%\end{array}$} & \multicolumn{2}{|c|}{$\begin{array}{l}\text { Pour } \\
n \% \\
\end{array}$} & \multicolumn{2}{|c|}{$\begin{array}{l}\text { Total } \\
n \% \\
\end{array}$} & \\
\hline Age Group & & & & & & & & & & & & & & & & & & & & & \\
\hline $26-30$ & 43 & 89,58 & 5 & 10,4 & 48 & 100 & & 46 & 95,83 & 2 & 4,17 & 48 & 100 & & 2 & 4,17 & 46 & 95,8 & 48 & 100 & \\
\hline $39-35$ & 32 & 82.05 & 7 & 18 & 39 & 100 & & 37 & 94.87 & 2 & 5,13 & 39 & 100 & & 0 & 0 & 39 & 100 & 39 & 100 & \\
\hline $36-40$ & 8 & 72,73 & 3 & 27,3 & 11 & 100 & 0.502 & 10 & 90,91 & 1 & 9,09 & 11 & 100 & 0,28 & 1 & 9,09 & 10 & 90,9 & 11 & 100 & 0.253 \\
\hline$x=41$ & 14 & 82,35 & 3 & 17,7 & 17 & 100 & & 14 & 82,35 & 3 & 17,65 & 17 & 100 & & 2 & 11,8 & 16 & $\mathrm{a}, 2$ & 17 & 100 & \\
\hline total & 97 & 84,35 & 18 & 15,7 & 115 & 100 & & 107 & 93,04 & 8 & 6,96 & 115 & 100 & & 5 & 4,35 & 110 & 95,7 & 115 & 100 & \\
\hline \multicolumn{22}{|c|}{ Experience After Graduation } \\
\hline $1-10$ years & 74 & 85,06 & 13 & 14,9 & 87 & 100 & & 82 & 94,25 & 5 & 6,75 & 87 & 100 & & 2 & 2,3 & 85 & 97,7 & 87 & 100 & \\
\hline $11-20$ years & 20 & 86.96 & 3 & 13 & 23 & 100 & 0,302 & 21 & 91,3 & 2 & 8,7 & 23 & 100 & 0,45 & 2 & 8,7 & 21 & 91,3 & 23 & 100 & 0,088 \\
\hline$>20$ years & 3 & 60 & 2 & 40 & 5 & 100 & & 4 & 80 & 1 & 20 & 5 & 100 & & 1 & 20 & 4 & 80 & 5 & 100 & \\
\hline total & 97 & 84,35 & 18 & 15,7 & 115 & 100 & & 107 & 93,04 & 8 & 6,96 & 115 & 100 & & 5 & 4,35 & 110 & 95.7 & 115 & 100 & \\
\hline \multicolumn{22}{|l|}{ Gender } \\
\hline Male & 18 & 75 & 6 & 25 & 24 & 100 & & 22 & 91,67 & 2 & 8,33 & 24 & 100 & & 1 & 4,17 & 23 & 95,8 & 24 & 100 & \\
\hline Female & 79 & 86.81 & 12 & 13,2 & 91 & 100 & 0,21 & 85 & 93,41 & 6 & 6,59 & 91 & 100 & 0,77 & 4 & 4,4 & 87 & 95,6 & 91 & 100 & 0,96 \\
\hline Tolal & 97 & 84,35 & 18 & 15,7 & 115 & 100 & & 107 & 93.04 & 8 & 6,96 & 115 & 100 & & 5 & 4,35 & 110 & 95,7 & 115 & 100 & \\
\hline \multicolumn{22}{|l|}{ Sub Area } \\
\hline Bojonagara (west) & 16 & 88.89 & 2 & 11,1 & 18 & 100 & & 18 & 100 & 0 & 0 & 18 & 100 & & 0 & 0 & 18 & 100 & 18 & 100 & \\
\hline Tegalega (west) & 18 & 85,71 & 3 & 14,3 & 21 & 100 & & 20 & 95.24 & 1 & 4,76 & 21 & 100 & & 2 & 9,53 & 19 & 90,5 & 21 & 100 & \\
\hline Cibeunying (west) & 14 & 63,64 & 8 & 36,4 & 22 & 100 & & 19 & 86.36 & 3 & 13.64 & 22 & 100 & & 0 & 0 & 22 & 100 & 22 & 100 & \\
\hline Karees (west) & 16 & 100 & 0 & 0 & 16 & 100 & & 13 & 81.25 & 3 & 18,75 & 16 & 100 & & 1 & 6,25 & 15 & 93,8 & 16 & 100 & \\
\hline Arcamanik (east) & 12 & 80 & 3 & 20 & 15 & 100 & 0.112 & 15 & 100 & 0 & 0 & 15 & 100 & 0,11 & 1 & 6,67 & 14 & 93,3 & 15 & 100 & 0,759 \\
\hline Ujungberung (east) & 13 & 92.86 & 1 & 7,14 & 14 & 100 & & 14 & 100 & 0 & 0 & 14 & 100 & & 1 & 7,14 & 13 & 92,9 & 14 & 100 & \\
\hline Kordon (east) & 7 & 87,5 & 1 & 12,5 & 8 & 100 & & 7 & 87,5 & 1 & 12.5 & 8 & 100 & & 0 & 0 & 8 & 100 & 8 & 100 & \\
\hline Gedobage (cast) & 1 & 100 & 0 & 0 & 1 & 100 & & 1 & 100 & 0 & 0 & 1 & 100 & & 0 & 0 & 1 & 100 & 1 & 100 & \\
\hline Total & 97 & 84,35 & 18 & 15,7 & 115 & 100 & & 107 & 93,04 & 8 & 6,96 & 115 & 100 & & 5 & 4,35 & 110 & 95,7 & 115 & 100 & \\
\hline \multicolumn{22}{|c|}{ Ophthaimoscope Availability } \\
\hline Available & 15 & 88.24 & 2 & 11.8 & 17 & 100 & 0,633 & 14 & 82,35 & 3 & 17,65 & 17 & 100 & 0.01 & 4 & 23.5 & 13 & 76.5 & 17 & 100 & 0,00038 \\
\hline Not Available & 82 & 83,67 & 16 & 16,3 & 98 & 100 & & 93 & 94,9 & 5 & 5,1 & 98 & 100 & & 1 & 1,02 & 97 & 99 & 98 & 100 & \\
\hline Total & 97 & 84,35 & & 15,7 & 115 & 100 & & 107 & 93,04 & 8 & 6,96 & 115 & 100 & & 5 & 4,35 & 110 & 95,7 & 115 & 100 & \\
\hline
\end{tabular}




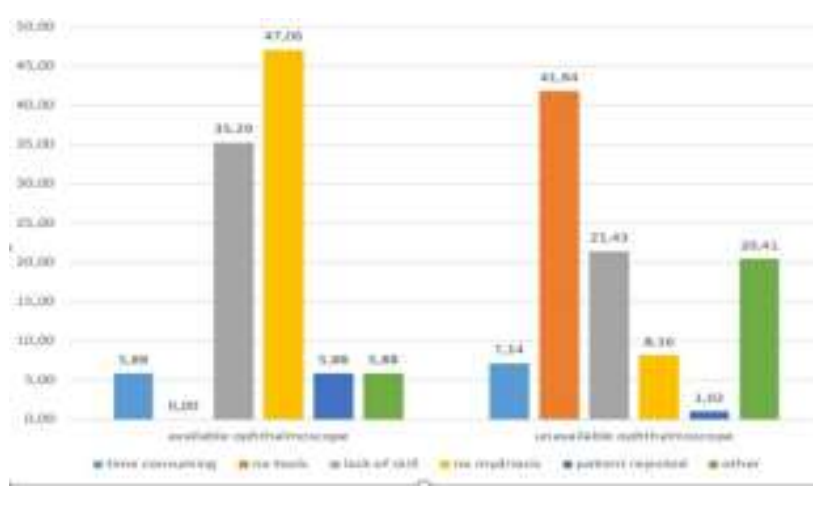

Diagram 5. Barriers For Fundus Examination Among GPs

\section{DISCUSSION}

In this study, the participants were recruited in the peak period of the COVID-19 pandemic between April to June 2019. Almost half of GPs in Puskesmas of Bandung City refused to participate in this as they had duties as front line officers coping with the pandemic. Therefore, purposive sampling was done to all 115 GPs who were willing to participate in this study.

Almost $80 \%$ of participants were females, with a median of 31 years old, ranging from 26 to 58 years old. It might be related to female GPs being married and established in the city without leaving the families working in a rural area. Most of the participants had 1-10 years of working experience after graduation. Due to National rule on the placement of medical practitioners, fresh graduates are assigned toto fulfill community demand at the primary level as a medical officer. Senior practitioners will improve their career path as a leader. ${ }^{6,7}$

Ophthalmoscope is an essential medical device that must be available in primary health care according to the rule of Indonesia Health Ministry (PMK) number $29 / 2016$. This study revealed that only 17 participants from 15 out of 61 Puskesmas had a direct ophthalmoscope. Step-wise procurement of medical instrument with new provisions of ministry from the year of 20165 might have caused this unavailability.

GPs should use Knowledge on fundus examination for diabetic patients according to the 4A level of competency for GPs in Indonesia.4 Most of the participants had good Knowledge about eye/ fundus check timing for diabetic patients. However, only $20.87 \%$ of participants were familiar with fundus check timing for pregnant women with diabetes. Even though retinopathy progression occurs at approximately double the rate in pregnant women than in non-pregnant women, 8 GPs might have not realize the effect of pregnancy on DR. DR generally occurs in type 1 Diabetes Mellitus, which is minority than type 2 . DR has a definite tendency for regression in the post-natal period, and if the retinopathy is stable after delivery, there is no risk of progression with subsequent pregnancies.9

Most of the participants had good Knowledge about DR fundus signs, except the macular degeneration. Only 9,57\% of participants answered that macular degeneration is not part of the diabetic fundus sign. Basically, these two diseases are pathogenesis were different, but they could simultaneously develop in diabetic patients. It is reasonable that our study revealed a tendency of wrong answer to this question among the GPs, correlated with a study in Taiwan in 2018. This study revealed that patients with diabetes had a 1.4 -fold increased macular degeneration over matched patients without diabetes. 10

Almost all participants (93.04\%) had a good Attitude on fundus examination on diabetic patients. Most were competent in basic concepts of fundus examination. However, more than half of the participants felt that fundus examination training during medical education was insufficient.

In this study, no significant demographic characters were related to the level of Knowledge and Attitude. This result was similar to a study in 
Riyadh and Nigeria.11,12 Although, there were some specific characters for poor Knowledge and Attitude, which were dominated by age above 35 years old and working experience more than 20 years. It might be related to Verner and Davidson Theory about age-related psychological aspects involving the way of learning and thinking that would reduce memory and learning ability.13

Conversely, almost all participants (95.65\%) had poor Practice on fundus examination on diabetic patients. Age, gender, experience, and geographical area did not influence Practice on fundus examination, but it was strongly related to the availability of ophthalmoscope $(p=0,00038)$. This result was similar to a study in Nigeria.12

Unavailability of an ophthalmoscope in the clinic was the biggest barrier for GPs to perform fundus examination., barriers were divided into two groups, with and without ophthalmoscope access in the clinic. The main barrier for the group with ophthalmoscope access was no mydriatics to dilate the pupil, followed by a lack of skill, timeconsuming, and patient rejection. The main barrier for the group without ophthalmoscope access was a lack of ophthalmoscope, followed by a lack of skill, no mydriatics to dilate the pupil, timeconsuming, and patient rejection. It was reasonable that our study revealed that $76 \%$ of participants who had access to direct ophthalmoscope had poor Practice.

Mydriatics for pupil dilating was not supported in the Primary Health Care level since the purpose of direct ophthalmoscope was limited to check media clearance only.7 Along with increasing DR cases, the purpose of the direct ophthalmoscope in Primary Health Care should be changed and need the government's advocation approach. Otherwise, pupil dilatation needs more time in the examination process, becoming one of the barriers. Patients discomfort after pupillary dilatation made them reject the examination. It needs improvement of skills to examine the fundus without dilating the pupil. Lack of skill among GPs should be addressed with intensive training during medical school as part of their $4 \mathrm{~A}$ level of competency. This study was part of the KAP study of Diabetic Retinopathy Screening Study among GPs and discuss about fundus examination. Other secondary result of study will publish in different manuscripts. This study was the first in Bandung City and in Indonesia. Study limitations were, limited participants during the COVID-19 pandemic, and researchers being incapable of interviewing participants directly and observing the instruments availability. This article consists of KAP value only, and other secondary outcomes will be published in different articles.

\section{CONCLUSION}

Knowledge and Attitude among GPs in Puskesmas of Bandung City was good, but Poor Practice on fundus examination of diabetic patients by the GPs couldn't be excluded. The main barrier for GPs with ophthalmoscopes access was the unavailability of mydriatics, and the main barrier for GPs without ophthalmoscope access was not having an ophthalmoscope. Therefore advocating relevant authorities to provide ophthalmoscopes and mydriatics to Puskesmas is necessary. Overall, direct ophthalmoscopy was a difficult tasks for GPs. In the future, innovation of simple and user-friendly instruments that could replace the direct ophthalmoscope as standard fundus examination tools in Primary Health Care is required.

\section{REFERENCES}

1. Switania A, Halim A. Risk Factors Of Diabetic Retinopathy And Vision Threatening Diabetic Retinopathy Based On Diabetic Retinopathy Screening Program In Greater Bandung, West Java. Bandung, 2018. Available 
from

https://www.google.com/url?sa=t\&source= web\&rct=j\&url=http://perpustakaanrsmcic endo.com/2019/04/15/risk-factors-of-

diabetic-retinopathy-and-vision-

threatening-diabetic-retinopathy-andvision-threatening-diabetic-retinopatybased-on-diabetic-retinopathy-screeningprogram-in-greater-bandung-westjav/\&ved=2ahUKEwjE_OiKzaPsAhWjkOYKH dSxBT8QFjAAegQIBRAB\&usg = AOvVaw28x7 Uc3IVOZ0N8pgjamEoJ :

2. Ryan Lee, Wong TY, Sabanayagam C. Epidemiology of diabetic retinopathy, diabetic macular edema, and related vision loss. Eye Vis.2015;2(17). Available from: https://www.ncbi.nlm.nih.gov/pmc/articles/ PMC4657234/\#! po=0.806452.

3. BPJS. Peraturan BPJS nomor 2 tahun 2019 tentang Pelaksanaan Skrining Riwayat Kesehatan dan Pelayanan Penapisan atau Skrining Kesehatan Tertentu Serta Peningkatan Kesehatan Bagi Peserta Penderita Penyakit Kronis Dalam Jaminan Kesehatan. BPJS;2019. Available from : https://bpjs-

kesehatan.go.id/bpjs/dmdocuments/a4d81 1d5cc2b9e2c674d9d0f4a5e71c4.pdf

4. Konsil Kedokteran Indonesia. Standar Kompetensi Dokter Indonesia. Edisi 2. KKl; 2012. Available from : http://www.kki.go.id/assets/data/arsip/SKDI _Perkonsil,_11_maret_13.pdf

5. Kementerian Kesehatan Republik Indonesia. Peraturan Menteri Kesehatan Republik Indonesia Nomor 29 Tahun 2016 Tentang Penyelenggaraan Pelayanan Kesehatan Mata di Fasilitas Pelayanan Kesehatan. Kementerian Kesehatan Rl;2016.1-42. Available from: https://www.regulasip.id/book/5043/read

6. Kementerian Kesehatan Republik Indonesia. Peraturan Menteri kesehatan nomor 7 tahun 2017 tentang Pedoman Pengangkatan dan Penempatan Dokter dan Bidan Sebagai Pegawai Tidak Tetap. Kementerian Kesehatan RI ;2017.1-16. Available from : http://hukor.kemkes.go.id/uploads/produk_
hukum/PMK_No._7_ttg_Penggunaan_Logo_ Kementerian_Kesehatan_.pdf

7. Pemerintah Republik Indonesia. Peraturan Pemerintah nomor 11 tahun 2017 tentang Manajemen Pegawai Negeri Sipil. 2017. Available from https://bpptik.kominfo.go.id/download/ppno-11-tahun-2017-tentang-manajemenpegawai-negeri-sipil/

8. Julie $L$, Lauren $A B$, Lyndell $L$, Salman $A Q$. Diabetic Retinopathy in Pregnancy: A Review. Clinical and Experimental Ophthalmology. 2016; 44:321-334. Available from:

https://onlinelibrary.wiley.com/doi/epdf/10. 1111/ceo.12760

9. PS Mallika1 MS; AK Tan1 MD; S Aziz2 MS; T Asok2 MMed; SAR Syed Alwi3 MMed; G Intan2 MS. Diabetic Retinopathy and The Effect of Pregnancy. Malaysian Family Physician. 2010; 5(1). Available from: https://www.ncbi.nlm.nih.gov/pmc/articles/ PMC4170393/

10. Ming-Shan $\mathrm{He}_{\text {, }}$ Fang-Ling Chang1, HongZin Lin1, Jung-Lun Wu3, Tsung-Cheng Hsieh, Yuan-Chieh Le. The Association Between Diabetes and Age-Related Macular Degeneration Among the Elderly in Taiwan. Diabetic Care, Volume 41, October 2018. Available from: https://www.hindawi.com/journals/joph/20 19/1649156/

11. Raghad Al Rasheed, Fadwa Al Adel. Article Diabetic retinopathy: Knowledge, Awareness, and Practices of Physicians in Primary Care Centers in Riyadh, Saudi Arabia. Saudi Journal of Ophthalmology. 2017;31(1): 2-6. Available from https://www.ncbi.nlm.nih.gov/pmc/articles/ PMC5352944/

12. A. A., Onua, B. Fiebai, Knowledge and Practice of Fundoscopy among Medical Doctors in Port Harcourt, Nigeria. Open Journal of Ophthalmology. 2016; 6: 164-169. Available from: https://www.researchgate.net/publication/3 06342999_Knowledge_and_Practice_of_Fun doscopy_among_Medical_Doctors_in_Port_ 
Harcourt_Nigeria13.

13. Jauhan Budiwan.Pendidikan Orang Dewasa (Andragogy). Qalamuna. 2018; 10(2). Available from: https://ejournal.insuriponorogo.ac.id/index. php/qalamuna/article/view/147

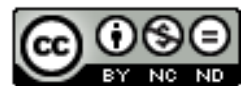

This work licensed under Creative Commons Attribution 